\begin{tabular}{|l|l|l||}
\hline \multicolumn{2}{|c|}{ PublisherInfo } \\
\hline \hline PublisherName & $:$ & BioMed Central \\
\hline \hline PublisherLocation & $:$ & London \\
\hline \hline PublisherImprintName & $:$ & BioMed Central \\
\hline \hline
\end{tabular}

\title{
Primitive microbe enlightens evolution
}

\begin{tabular}{||l|l|l||}
\hline \multicolumn{2}{|c|}{ ArticleInfo } \\
\hline \hline ArticleID & $:$ & 4284 \\
\hline \hline ArticleDOI & $:$ & $10.1186 /$ gb-spotlight-20011227-01 \\
\hline \hline ArticleCitationID & $:$ & spotlight-20011227-01 \\
\hline \hline ArticleSequenceNumber & $:$ & 355 \\
\hline \hline ArticleCategory & $:$ & Research news \\
\hline ArticleFirstPage & $:$ & 1 \\
\hline \hline ArticleLastPage & $:$ & 2 \\
\hline \hline & & \\
\hline ArticleHistory & $:$ & RegistrationDate : 2001-12-27 \\
\hline \hline ArticleCopyright & $:$ & OnioMed Central Ltd2001 \\
\hline \hline ArticleGrants & $:$ & \\
\hline \hline ArticleContext & $:$ & 130592211 \\
\hline \hline
\end{tabular}




\section{Tudor Toma}

Email: t.toma@ic.ac.uk

Choanoflagellates are primitive microorganisms whose evolutionary roots can be traced to the era of the first multicellular animals (metazoans). In December 18 Proceedings of the National Academy of Sciences, Nicole King and Sean Carroll from University of Wisconsin show for the first time that singlecelled choanoflagellates have a receptor tyrosine kinase that is not found in other eukaryotes and that may be linked to the origin of metazoa.

King and Carroll compared expressed genes from choanoflagellates and animals to study the early evolution of metazoan genomes. They found in Monosiga brevicollis the first receptor tyrosine kinase (RTK) identified outside of the metazoa, MBRTK1. The architecture of MBRTK1 - which includes multiple extracellular ligand-binding domains - resembles that of RTKs in sponges and humans and suggests the ability to receive and transduce signals (Proc Natl Acad Sci USA 2001, 98:15032-15037).

"We believe we can discover in this organism more elements of the genetic toolkit that was first used to build animals," said Carroll.

\section{References}

1. King N and Carroll SB: A receptor tyrosine kinase from choanoflagellates: Molecular insights into early animal evolution. Proc Natl Acad Sci USA 2001, 98:15032-15037., [http://www.pnas.org/cgi/ content/abstract/98/26/15032]

2. University of Wisconsin, [http://www.wisc.edu/] 